\title{
Vertical distribution and diel migration in the iridescent copepods of the family Sapphirinidae: a unique example of reverse migration?
}

\author{
Jinho Chae, Shuhei Nishida \\ Ocean Research Institute, University of Tokyo, 1-15-1 Minamidai, Nakano, Tokyo 164, Japan
}

\begin{abstract}
The vertical distributions and diel vertical migrations of the sapphirinid copepods of the genera Sapphirina and Copilia were investigated in the tropical and subtropical waters in the eastern Indian Ocean, the South China Sea and the western Pacific. Vertically stratified plankton samples were collected at a total of 11 stations including 5 day-night stations and 1 station occupied for a 20 h serial sampling, in the years $1977,1981,1988$ and 1991. The sapphirinids, the family as a whole, were collected essentially in the upper $200 \mathrm{~m}$, and are considered as typical epipelagic copepods. Three groups of species were recognized according to their patterns of vertical distributions: the upper epipelagic species, the lower epipelagic species, both of the genus Sapphirina, and 2 species of Copilia which showed relatively deep and broad vertical distributions. Marked reverse diel vertical migrations were observed in the upper epipelagic species, S gastrica, S. stellata, S. nigromaculata and S. auronitens, and, to a lesser extent, in the lower epipelagic species, $S$. metallina. In the species exhibiting reverse migrations, the vertical distributions in the daytime were mostly unimodal, while bimodal distributions were occasionally observed at night. A comparison of these vertical patterns with the specific iridescent color patterns in the male and the distribution of light in the ocean suggested that the daytime distributions of the sapphirinids are determined by the underwater light condition as a proximate cue. It was also hypothesized that the well-developed eye, the iridescence of the male and the daytime shoaling in the sapphirinids are closely related and constitute a presumed mate-finding mechanism which may be unique in the oceanic plankton.
\end{abstract}

KEY WORDS: Sapphirina - Copilia - Reverse migration - Iridescence · Ambient light

\section{INTRODUCTION}

The sapphirinid copepods are distributed widely in the tropical and subtropical waters of the world oceans (e.g. Lehnhofer 1926, 1929, Sewell 1947). Although they rarely predominate in epipelagic copepod communities, their unique characteristics have been called to the attention of many biologists since the early 19th century. Their most striking characteristic is the iridescence of the male (e.g. Dana 1852, Schmidt 1949). This iridescence is generated by the reflection of light that is interfered through the multilayered platelets in the epidermal cells of the dorsal integument, and has spectral ranges peculiar to each species that are partly dependent on the thickness of the reflecting platelets (Chae \& Nishida 1994). The sapphirinids also have scanning eyes which are unique to only a few copepod taxa (Gregory et al. 1964, Elofsson 1969, Moray 1972, Land 1981, 1984). Some sapphirinids are also known to be associated with salps, as indicated by the coincident occurrence of these 2 groups (Hardy 1936, Furuhashi 1966) and by direct underwater and laboratory observations of their behavior (Heron 1973). The sapphirinids also share uniqueness with such groups as oncaeids and corycaeids in that they are referred to as pelagic copepods, but belong to Poecilostomatoida, whose members are mostly parasitic on or associated with benthic invertebrates and fishes (Ho 1991, Huys \& Boxshall 1991).

Among these characteristics, the iridescence and the eye are optical attributes which may be related to the vertical heterogeneity of light conditions in the ocean, while parasitism may be related to the vertical heterogeneity of other pelagic organisms. Therefore, for a bet- 
ter understanding of the ecology and evolution of the sapphirinids, it is necessary to examine the relationships between these characteristics and the mode of existence of sapphirinids in the ocean, particularly the patterns of their vertical distribution. Sapphirinids are known to occur in the epipelagic zone of the ocean, mainly in the upper $200 \mathrm{~m}$ (Boxshall 1977. Rajaram \& Krishnaswamy 1981, BöttgerSchnack 1990 a, b), but available data are limited to only a few common species; detailed distributional patterns within the epipelagic zones have not been well investigated for most species.

This study examines the vertical distribution and diel migration patterns of species of Copilia and Sapphirina, the most common members of the family Sapphirinidae, in the eastern Indian Ocean, the South China Sea and the tropical and subtropical western Pacific. Possible relationships between their vertical distributions and diel migrations, and the iridescent color patterns and environmental factors are discussed with particular reference to their unique reverse migration.

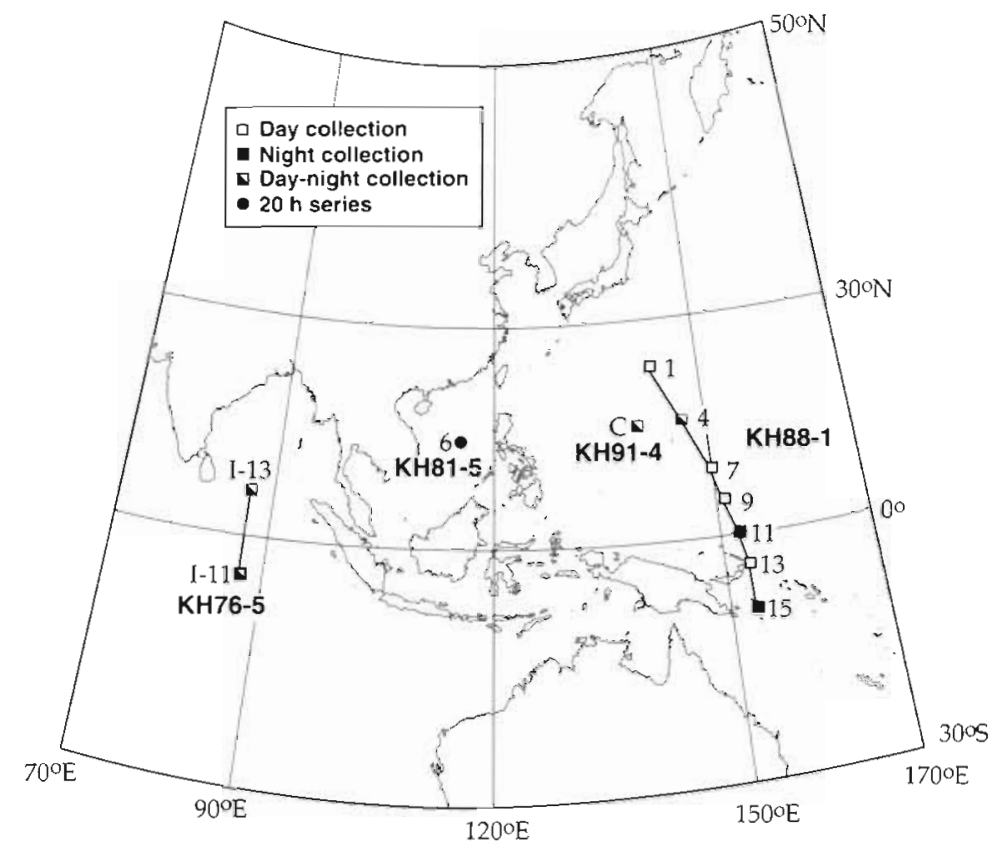

Fig. 1. Study area and sampling stations ' $K H$ ' indicates cruise number
Table 1. Data on the MTD net collections. (D), (N): day, night collections

\begin{tabular}{|c|c|c|c|}
\hline $\begin{array}{l}\text { Cruise } \\
\text { Station }\end{array}$ & Date & Local time $(\mathrm{h})$ & Location (middle point) \\
\hline \multicolumn{4}{|l|}{$\mathrm{KH}-76-5$} \\
\hline $\mathrm{I}-11(\mathrm{~N})$ & $24 \operatorname{Jan} 1977$ & $01: 32-02: 05$ & $04^{\circ} 52.2^{\prime} \mathrm{S}, \quad 87^{\circ} 04.8^{\prime} \mathrm{E}$ \\
\hline I-11 (D) & & $12: 13-12: 45$ & $04^{\circ} 47.9^{\prime} \mathrm{S}, \quad 87^{\circ} 12.9^{\prime} \mathrm{E}$ \\
\hline $\mathrm{I}-13(\mathrm{~N})$ & $8 \mathrm{Feb}$ & $00: 35-01: 11$ & $05^{\circ} 02.4^{\prime} \mathrm{N}, \quad 86^{\circ} 47.4^{\prime} \mathrm{E}$ \\
\hline $\mathrm{I}-13$ (D) & & $14: 50-15: 23$ & $05^{\circ} 08.0^{\prime} \mathrm{N}, \quad 86^{\circ} 44.3^{\prime} \mathrm{E}$ \\
\hline \multicolumn{4}{|l|}{$\mathrm{KH}-81-5$} \\
\hline 6-1 & 3 Oct 1981 & $16: 33-17: 07$ & $14^{\circ} 56.6^{\prime} \mathrm{N}, 114^{\circ} 07.8^{\prime} \mathrm{E}$ \\
\hline $6-2$ & & $20: 24-20: 54$ & $14^{\circ} 55.3^{\prime} \mathrm{N}, 114^{\circ} 06.9^{\prime} \mathrm{E}$ \\
\hline $6-3$ & 4 Oct & $01: 02-01: 32$ & $14^{\circ} 53.5^{\prime} \mathrm{N}, 114^{\circ} 06.8^{\prime} \mathrm{E}$ \\
\hline $6-4$ & & $03: 57-04: 27$ & $14^{\circ} 52.8^{\prime} \mathrm{N}, 114^{\circ} 09.9^{\prime} \mathrm{E}$ \\
\hline $6-5$ & & $08: 06-08: 35$ & $14^{\circ} 52.5^{\prime} \mathrm{N}, 114^{\circ} 10.8^{\prime} \mathrm{E}$ \\
\hline $6-6$ & & $14: 03-14: 35$ & $14^{\circ} 53.8^{\prime} \mathrm{N}, 114^{\circ} 13.6^{\prime} \mathrm{E}$ \\
\hline \multicolumn{4}{|l|}{$\mathrm{KH}-88-1$} \\
\hline $1(\mathrm{D})$ & $25 \operatorname{Jan} 1988$ & $11: 20-11: 51$ & $24^{\circ} 58.9^{\prime} \mathrm{N}, 144^{\circ} 16.5^{\prime} \mathrm{E}$ \\
\hline 4 (D) & $28 \mathrm{Jan}$ & $13: 41-14: 10$ & $17^{\circ} 11.4^{\prime} \mathrm{N}, 147^{\circ} 50.5^{\prime} \mathrm{E}$ \\
\hline $4(N)$ & & $23: 05-23: 35$ & $17^{\circ} 13.9^{\prime} \mathrm{N}, 147^{\circ} 51.1^{\prime} \mathrm{E}$ \\
\hline 7 (D) & $31 \mathrm{Jan}$ & $07: 43-08: 12$ & $09^{\circ} 54.2^{\prime} \mathrm{N}, 150^{\circ} 01.5^{\prime} \mathrm{E}$ \\
\hline 9 (D) & 1 Feb & $13: 15-13: 43$ & $04^{\circ} 59.9^{\prime} \mathrm{N}, 151^{\circ} 14.7^{\prime} \mathrm{E}$ \\
\hline 11. $(\mathrm{N})$ & $2-3$ Feb & $23: 58-00: 28$ & $00^{\circ} 00.5^{\prime} \mathrm{S}, \quad 152^{\circ} 17.7^{\prime} \mathrm{E}$ \\
\hline 13 (D) & 4. Feb & $12: 34-13: 03$ & $04^{\circ} 57.6^{\prime} \mathrm{S}, \quad 153^{\circ} 26.4^{\prime} \mathrm{E}$ \\
\hline $15(\mathrm{~N})$ & $6 \mathrm{Feb}$ & $00: 47-01: 09$ & $09^{\circ} 56.7^{\prime} \mathrm{S}, \quad 154^{\circ} 12.3^{\prime} \mathrm{E}$ \\
\hline \multicolumn{4}{|l|}{$\mathrm{KH}-91-4$} \\
\hline$C(N)$ & 2 Jul 1991 & $00: 29-01: 01$ & $15^{\circ} 50.5^{\prime} \mathrm{N}, 136^{\circ} 54.5^{\prime} \mathrm{E}$ \\
\hline$C(D)$ & & $08: 1.5-08: 51$ & $15^{\circ} 51.2^{\prime} \mathrm{N}, 136^{\circ} 53.2^{\prime} \mathrm{E}$ \\
\hline
\end{tabular}

\section{MATERIALS AND METHODS}

Samples were collected during the cruises of the RV 'Hakuho Maru' of the Ocean Research Institute, University of Tokyo, during 1977, 1981, 1988 and 1991. In the eastern Indian Ocean (Cruise $\mathrm{KH}$ 76-5), collections of day-night series were made at 2 stations. In the South China Sea (Cruise KH-81-5), 6 series of tows were made at 2 to $6 \mathrm{~h}$ intervals for $20 \mathrm{~h}$ at 1 station. In the subtropical and tropical regions of the western Pacific Ocean (Cruise KH-88-1.), collections were made at 7 stations including 1 day-night series of tows at $\operatorname{Stn} 4$. Another day-night series was conducted in the eastern waters off the Philippines (Cruise KH-91-4) (Fig 1. Table 1). These sample series make it possible to examine both the longitudinal and latitudinal changes over a wide geographic range, and the diel patterns within the respective geographic regions.

Samples were collected by towing Motoda horizontal nets (MTD nets; Motoda 1971) with a $56 \mathrm{~cm}$ mouth diameter and a. $0.1 \mathrm{~mm}$ mesh aperture except for Cruise $\mathrm{KH}-91-4$ where nets with an $80 \mathrm{~cm}$ mouth diameter and a $0.5 \mathrm{~mm}$ mesh aperture were used. Collections were made in layers as deep as $1000 \mathrm{~m}$ at most stations. 
However, since the sapphirinids were essentially absent below $400 \mathrm{~m}$, the data are presented for the collections made at 7 to 10 different strata in the upper 200 or $400 \mathrm{~m}$. Details of the towing methods of the MTD nets are described in Nishida \& Marumo (1982). The depth of tow for each net was estimated from the readings of a mechanical time-depth meter (Yanagi Instrument Co., Ltd) attached to the deepest net, assuming a straight wire, for Cruises $\mathrm{KH}-81-5$ and $\mathrm{KH}-$ 88-1. For Cruises $\mathrm{KH}-76-5$ and $\mathrm{KH}-91-4$ the depth of tow was estimated from the wire lengths and angles. Immediately after collection, the samples were fixed and preserved in $10 \%$ formalin/seawater solution buffered with sodium tetraborate.

The specimens were identified and counted for the species of the genera Copilia and Sapphirina; all samples were examined in their entirety. The abundance of copepods was standardized to the number of individuals per $1000 \mathrm{~m}^{3}$ on the basis of the volume of water filtered, from readings of a flow meter attached to the mouth of the nets. The adult females, males and juveniles were counted separately. The juveniles included all immature copepodid stages (mostly Stage IV and V copepodids) collected with the nets.

An arbitrary limit was set up in deciding whether to adopt a value of copepod abundance in each sample; the data of a vertical series were adopted only when the maximum number of individuals per sample of the respective category of that series was 10 or more.

Weighted mean depth $(D)$ was calculated as $D=$ $\sum \mathrm{n}_{1} d_{i} / \sum \mathrm{n}_{i}$ (Pearre 1973, Roe et al. 1984) to define the depth stratum where the core population of each species was distributed. In the equation, $\mathrm{n}_{i}$ is the number of individuals per $1000 \mathrm{~m}^{3}$ at sampled depth $d_{l}$. Hydrographic parameters were measured for temperature, salinity and chlorophyll a (chl a) (Nishida \& Marumo 1982, Hirota 1987, Simidu 1990, Otake \& Tsukamoto 1994).

\section{RESULTS}

\section{Hydrographic conditions}

While the present investigation covers a wide geographic range, most stations showed the conditions typical of the thermally stratified, subtropical or tropical oceanic waters, which are characterized by a relatively shallow ( $<50 \mathrm{~m}$ ) surface mixed layer (see Wyrtki 1964 for definition), an underlying thermocline, and a deep chlorophyll maximum between 75 and $100 \mathrm{~m}$ with chl a concentrations of about 0.1 to $0.4 \mathrm{mg} \mathrm{m}^{-3}$ (Fig. 2; Stns I-11, I-13, 6, 7, 9, 11 and 15).
Eastern Indian Ocean

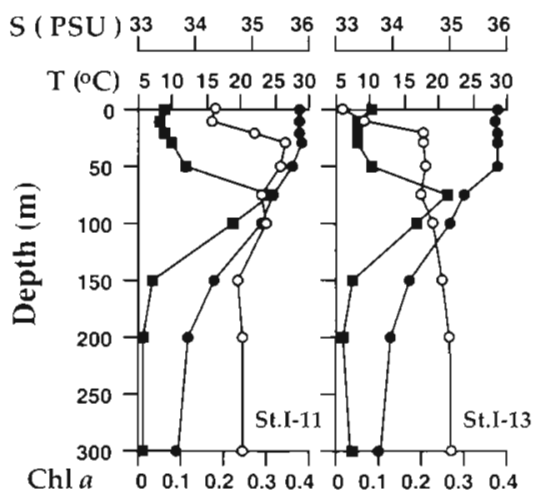

South China Sea
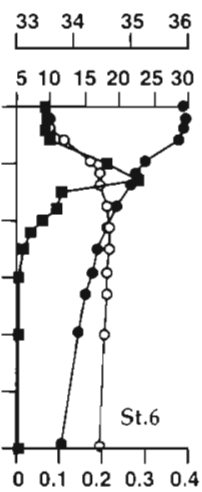

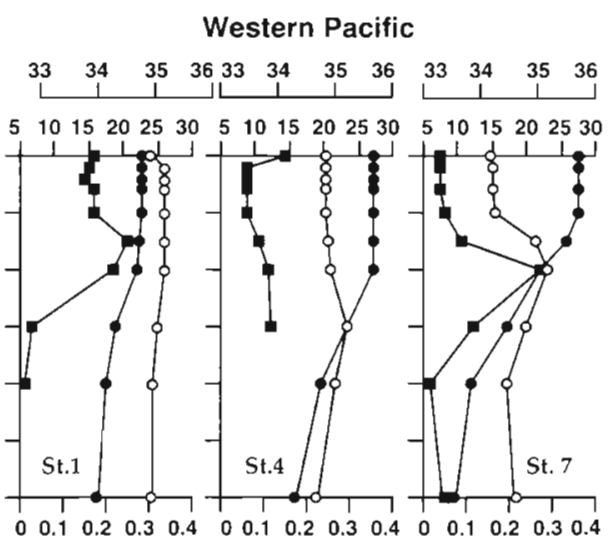
(mg m-3)

Fig. 2. Vertical profiles of water temperature $(T)$, salinity (S), and chlorophyll a (chl $a$, not measured at Stn C) in the studied area

\section{Western Pacific}

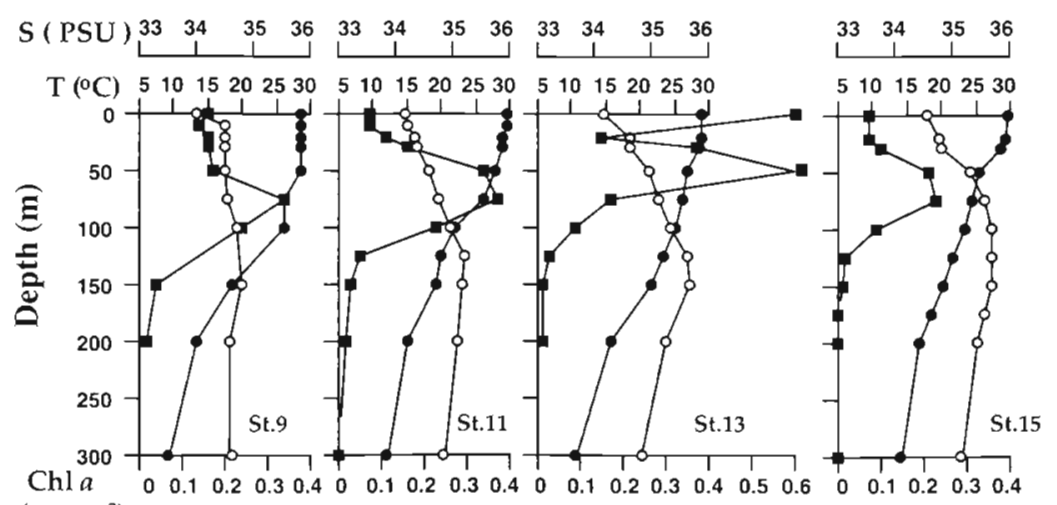

( $\mathrm{mg} \mathrm{m}^{-3}$ )
East of Philippines

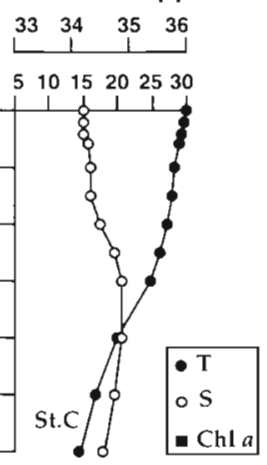


In the eastern Indian Ocean, an extremely low-salinity water existed at the surface at Stn I-13, which suggests an intrusion of coastal water.

At Stns 1, 4 and $C$ in the subtropical western Pacific, the surface mixed layer extended to $100 \mathrm{~m}$, and the seasonal thermoclines and the deep chlorophyll maximum diminished, particularly at Stn 4 (Fig. 2). A high chlorophyll concentration of about $0.6 \mathrm{mg} \mathrm{m}^{-3}$ was observed at the surface and at $50 \mathrm{~m}$ at Stn 13 (Fig. 2).

\section{Vertical distribution of species}

Among the 15 species of Sapphirina and 5 species of Copilia which occurred in the present samples, the vertical distributions are described below for 9 species of Sapphirina and 2 species of Copilia which were collected in sufficient numbers (Figs. 3 to 11).

Sapphirina auronitens Claus (Fig. 3). In the eastern Indian Ocean, most females were concentrated in the surface layer ( 0 to $10 \mathrm{~m}$ ) in the daytime, but were distributed from 0 to $30 \mathrm{~m}$ at Stn $\mathrm{I}-11$ and 0 to $75 \mathrm{~m}$ at Stn I-13 at night. The males were also distributed in the surface layer in the daytime at both stations. At night they occurred in the surface layer at Stn I-11, but in a deeper layer (50 to $75 \mathrm{~m}$ ) at Stn I-13. The vertical distributions of juveniles were almost identical to those of the females.

In the South China Sea, all females, males and juveniles were concentrated between 0 and $10 \mathrm{~m}$ in the daytime, but were almost completely absent from the night samples.
In the tropical and subtropical western Pacific, females and males were concentrated between 10 and $30 \mathrm{~m}$ at Stns 1 and 9 . At Stn 7, both females and males showed peaks at 0 and $50 \mathrm{~m}$. The females were scattered from 0 to $100 \mathrm{~m}$ at Stn 11, while males were concentrated at 30 and $50 \mathrm{~m}$. At Stn 15, females and males were distributed between 10 and $50 \mathrm{~m}$. Significant numbers of juveniles were collected at 0 and $10 \mathrm{~m}$ only at Stn 9.

Sapphirina gastrica Giesbrecht (Fig. 4). This species showed marked reverse diel vertical migration in the eastern Indian Ocean and the South China Sea. In the eastern Indian Ocean, the distribution of $S$. gastrica was quite similar to that of $S$. auronitens except for males and juveniles at Stn I-11 where the nighttime occurrence was detected as deep as 75 and $100 \mathrm{~m}$, respectively.

During the day-night time series in the South China Sea, both sexes stayed in the shallow layer in the daytime, while showing bimodal distribution at night with a smaller peak between 10 and $30 \mathrm{~m}$ and a larger peak between 50 and $100 \mathrm{~m}$.

In the subtropical and tropical waters of the western Pacific, significant numbers of individuals were collected only at Stn 9 in the upper $30 \mathrm{~m}$ in the daytime.

Sapphirina stellata Giesbrecht (Fig. 5). At Stn I-11 in the eastern Indian Ocean, only the daytime samples contained significant numbers of $S$. stellata, ranging between 10 and $30 \mathrm{~m}$ for both sexes. At Stn I-13, both sexes and juveniles were concentrated in the upper $10 \mathrm{~m}$ in the daytime, while at night the females and

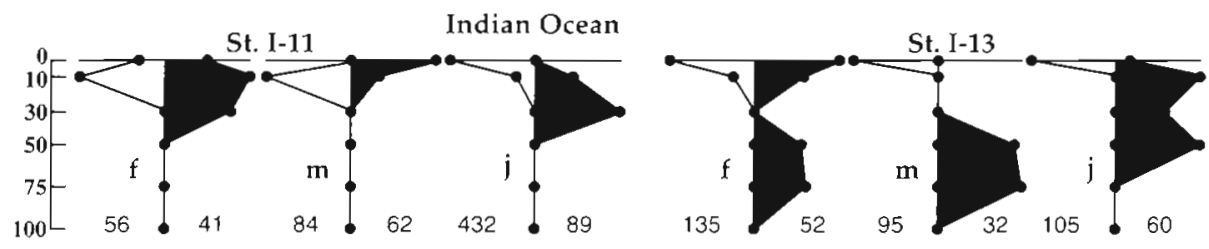

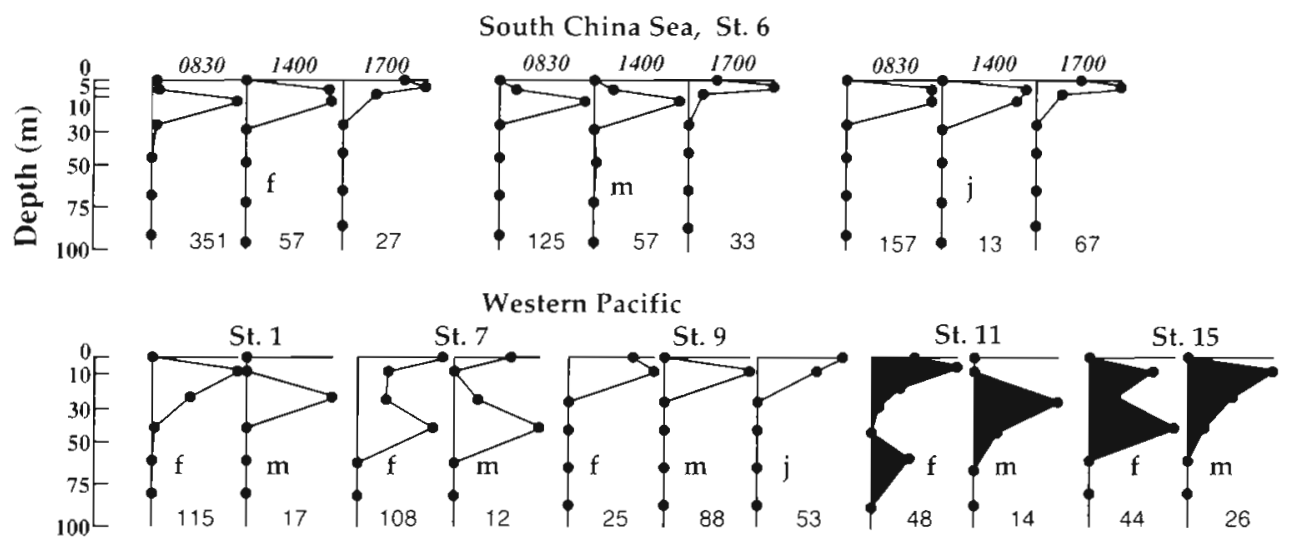

Fig. 3. Sapphirina auronitens. Vertical distribution of females ( $\mathrm{f})$, males $(\mathrm{m})$ and copepodid juveniles (j) in the Indian Ocean, the South China Sea and the western Pacific. Daytime collections are indicated by open areas, while nighttime collections by solid areas. Number at the base of each figure indicates number of individuals per $1000 \mathrm{~m}^{3}$ at the depth of maximum abun. dance. Approximate local times of collection are indicated in italics for the serial collection in the South China Sea 
Fig. 4. Sapphirina gastrica. Vertical distributions of females (f), males (m) and copepodid juveniles (j) in the Indian Ocean, the South China Sea and the western Pacific. Symbols as in Fig. 3
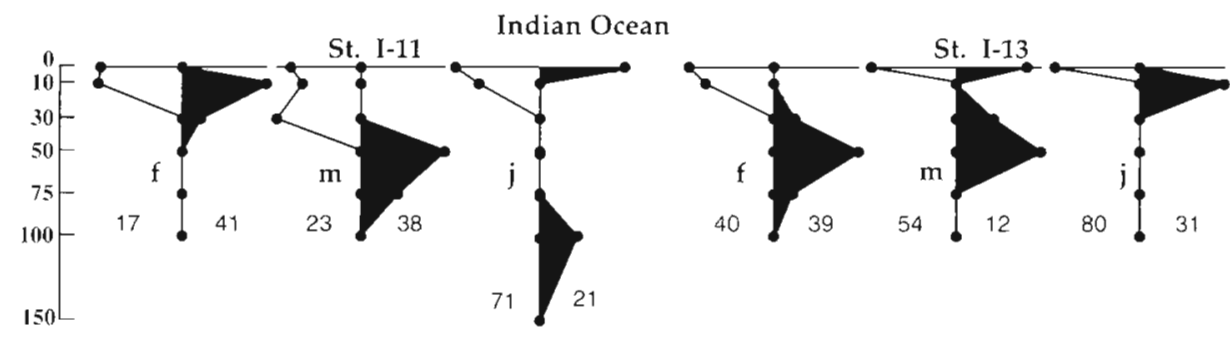

South China Sea, St. 6
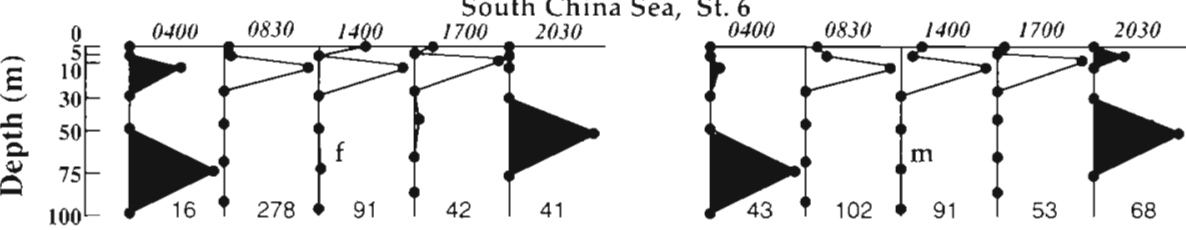

Western Pacific, St. 9

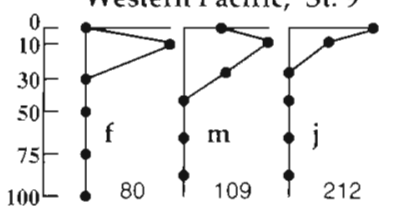

juveniles showed a bimodal distribution with peaks at 10 and $50 \mathrm{~m}$.

In the South China Sea, both females and males were in the upper $30 \mathrm{~m}$ during the day, while the females showed bimodal distribution at night with a major peak at $50 \mathrm{~m}$ and a minor peak at $5 \mathrm{~m}$; males were not collected at night.

In subtropical and tropical waters of the western Pacific, most Sapphirina stellata were distributed in the upper $30 \mathrm{~m}$ in the daytime, while extending as deep as $50 \mathrm{~m}$ at the nighttime stations.
In the eastern waters off the Philippines, both sexes showed marked reverse migration, with peaks at $25 \mathrm{~m}$ in the daytime and at $50 \mathrm{~m}$ at night

Sapphirina nigromaculata Claus (Fig. 6). In the eastern Indian Ocean, the depth ranges for females and males of $S$. nigromaculata in the daytime were broader than at night and showed bimodal distributions at Stn I-11, while the juveniles occurred only at $50 \mathrm{~m}$ during the day and between 0 and $50 \mathrm{~m}$ at night. At Stn $[-13$, both sexes and juveniles showed marked reverse migration, with peaks in the upper $10 \mathrm{~m}$ in the
Fig. 5. Sapphirina stellata Vertical distributions of females (f), males $(\mathrm{m})$ and copepodid juveniles (j) in the Indian Ocean, the South China Sea, the western Pacific and off the Philippines. Symbols as in Fig. 3
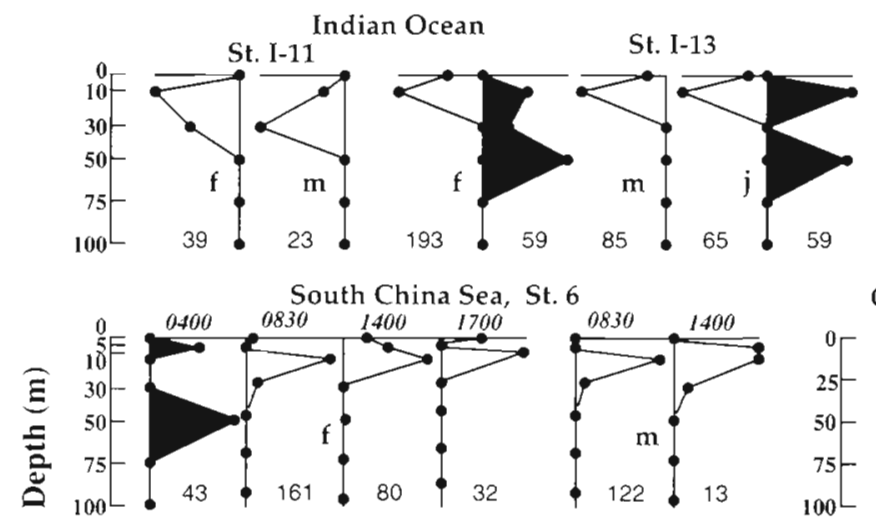

Off Philippines, St. C
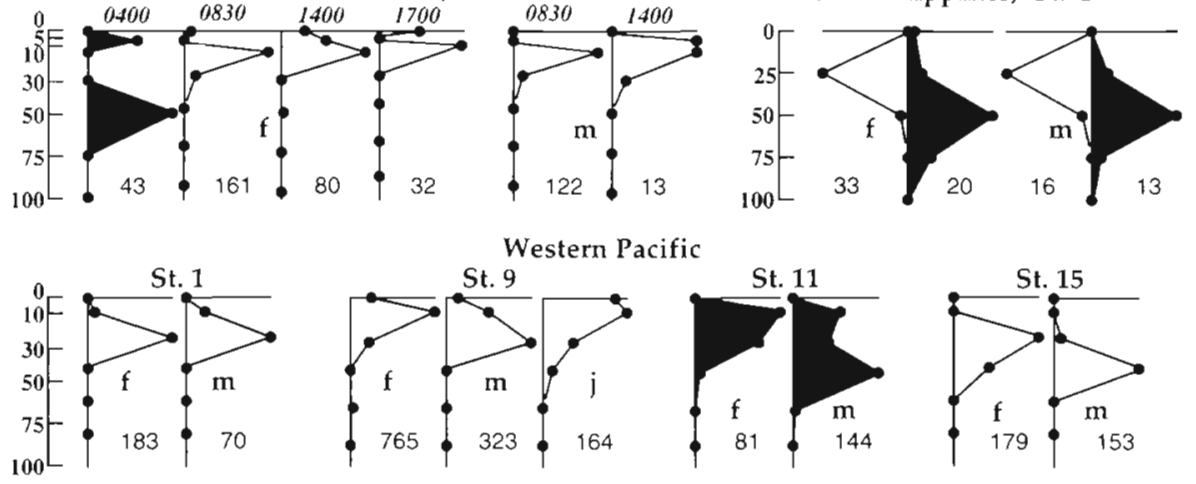


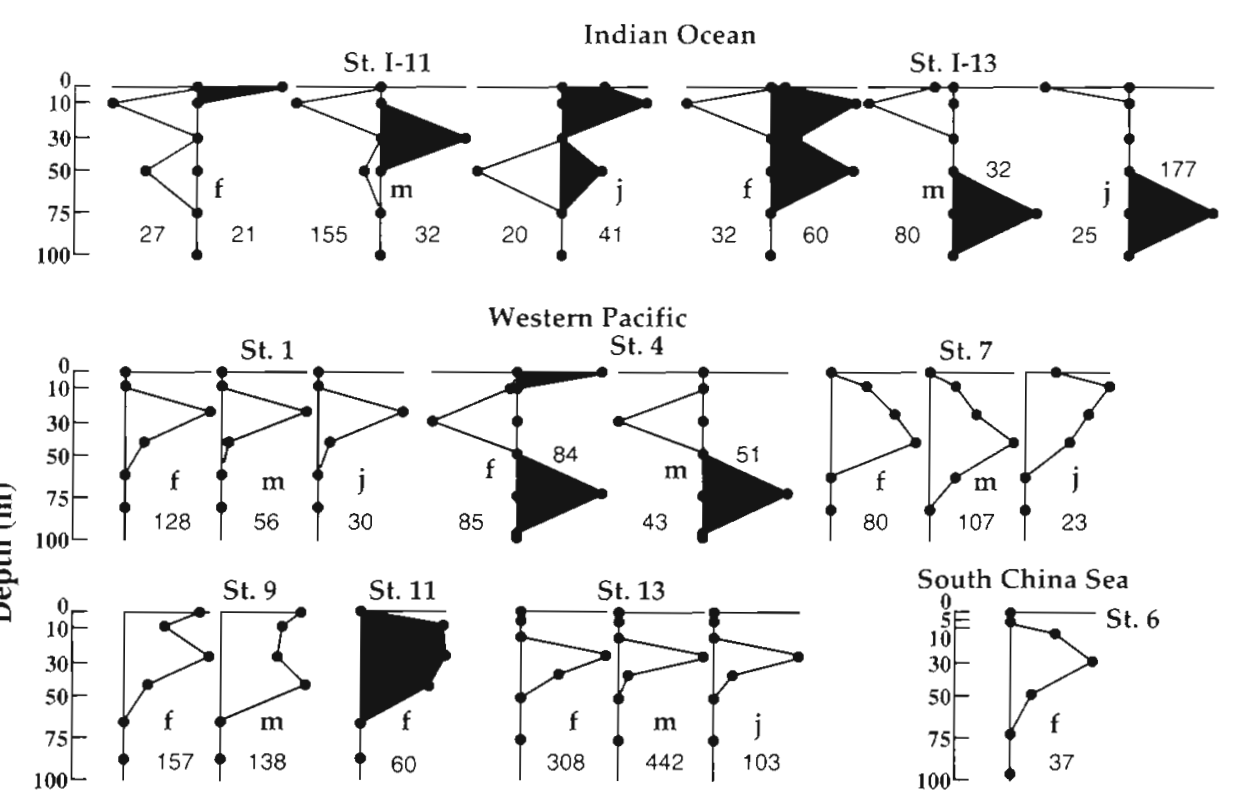

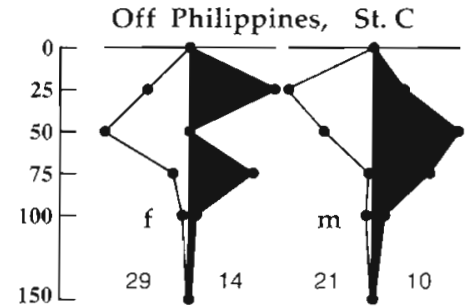

Fig. 6. Sapphirina nigromaculata. Vertical distributions of females (f), males $(\mathrm{m})$ and copepodid juveniles (j) in the Indian Ocean, the South China Sea, the western Pacific and off the Philippines. Symbols as in Fig. 3 daytime. At night, the females showed a bimodal pattern with peaks at 10 and $50 \mathrm{~m}$, while males and juveniles were concentrated at $75 \mathrm{~m}$. In the South China Sea, enough specimens were collected only in a daytime series with a peak at $30 \mathrm{~m}$.

In the subtropical and tropical waters of the western Pacific, Sapphirina nigromaculata showed peaks in the upper $50 \mathrm{~m}$ both during the day and at night at Stns 1 , 7,9 and 13. The considerable abundance of only this species at Stn 13 is notable, since this station is charac-

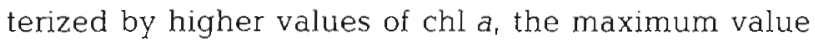
being nearly twice as much as those in the other stations (see 'Discussion'). At Stn 4, where a day-night series was obtained, a shallow daytime peak at $30 \mathrm{~m}$ and a deep nighttime peak at $75 \mathrm{~m}$ was observed in both sexes, with an additional surface occurrence at night of females.

In the eastern waters off the Philippines, the daytime peaks between 25 and $50 \mathrm{~m}$ were replaced by nighttime bimodal peaks at 25 and $75 \mathrm{~m}$ for females and a nighttime peak at $50 \mathrm{~m}$ for males.

Sapphirina metallina Dana (Fig. 7). Generally, the major distribution of $S$. metallina was slightly below the base of surface mixed layer (see also Fig. 13). At Stn I-11 of the eastern Indian Ocean, both sexes and the juveniles were distributed between 50 and $100 \mathrm{~m}$ with peaks at $75 \mathrm{~m}$ in the daytime. At night, females were distributed more widely than in the daytime from 30 to $150 \mathrm{~m}$ with peaks at 30 and $100 \mathrm{~m}$, while most males were distributed from 75 to $200 \mathrm{~m}$ with the highest concentration at $100 \mathrm{~m}$. Juveniles also showed a peak at $100 \mathrm{~m}$. At Stn I-13, both sexes and the juveniles exhibited similar patterns both during the day and at night with peaks at $75 \mathrm{~m}$.

In the South China Sea, a slight shoaling of the whole population was observed at about 08:30 $\mathrm{h}$ in females, males and juveniles, with peaks between 50 and $75 \mathrm{~m}$. At other times of the day they were in deeper layers, with peaks between 75 and $100 \mathrm{~m}$.

In the subtropical and tropical waters of the western Pacific, enough specimens were collected only at Stns 9 and 15, where most females and males were distributed between 75 and $100 \mathrm{~m}$, and 50 and $75 \mathrm{~m}$, respectively.

Sapphirina intestinata Giesbrecht (Fig. 8). This species showed distributions similar to $S$. metallina, i.e. the major populations were found below the mixed layer both during the day and at night. In the eastern Indian Ocean, most $S$. intestinata were distributed between 50 and $100 \mathrm{~m}$ both during the day and at night; no marked day-night difference was observed. 
Fig. 7. Sapphirina metallina. Vertical distributions of females (f), males (m) and copepodid juveniles ( $\mathrm{j}$ ) in the Indian Ocean, the South China Sea and the western Pacific. Symbols as in Fig. 3
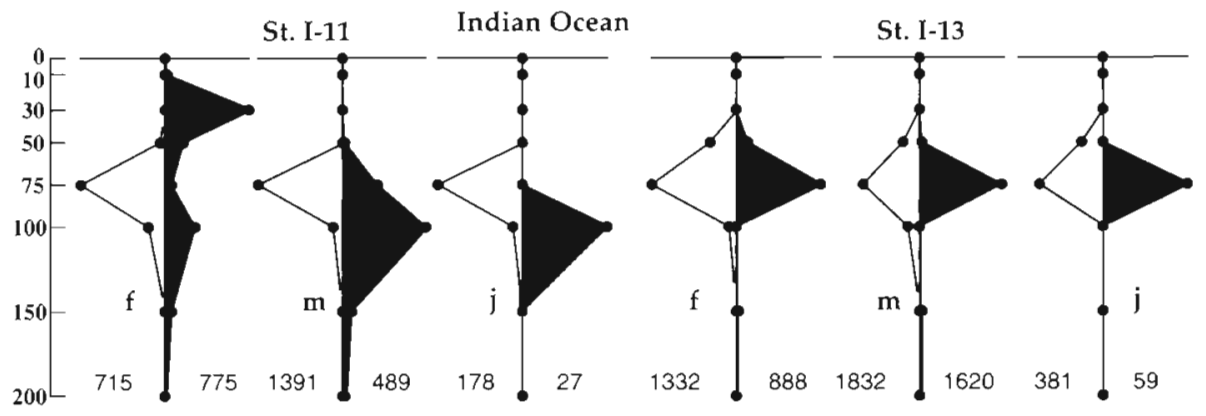

South China Sea, St. 6
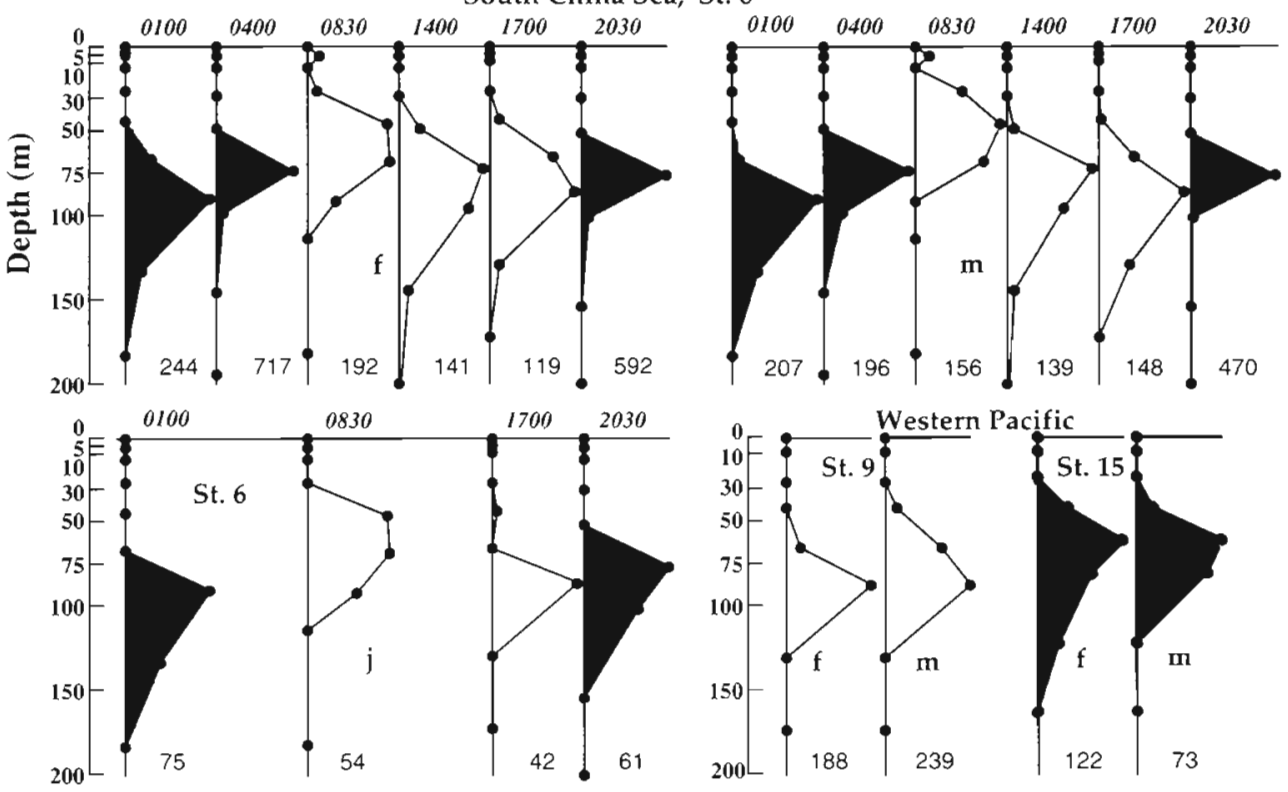

Fig. 8. Sapphirina intestinata. Vertical distributions of females (f), males ( $m$ ) and copepodid juveniles (j) in the Indian Ocean, the South China Sea and off the Philippines. Symbols as in Fig. 3

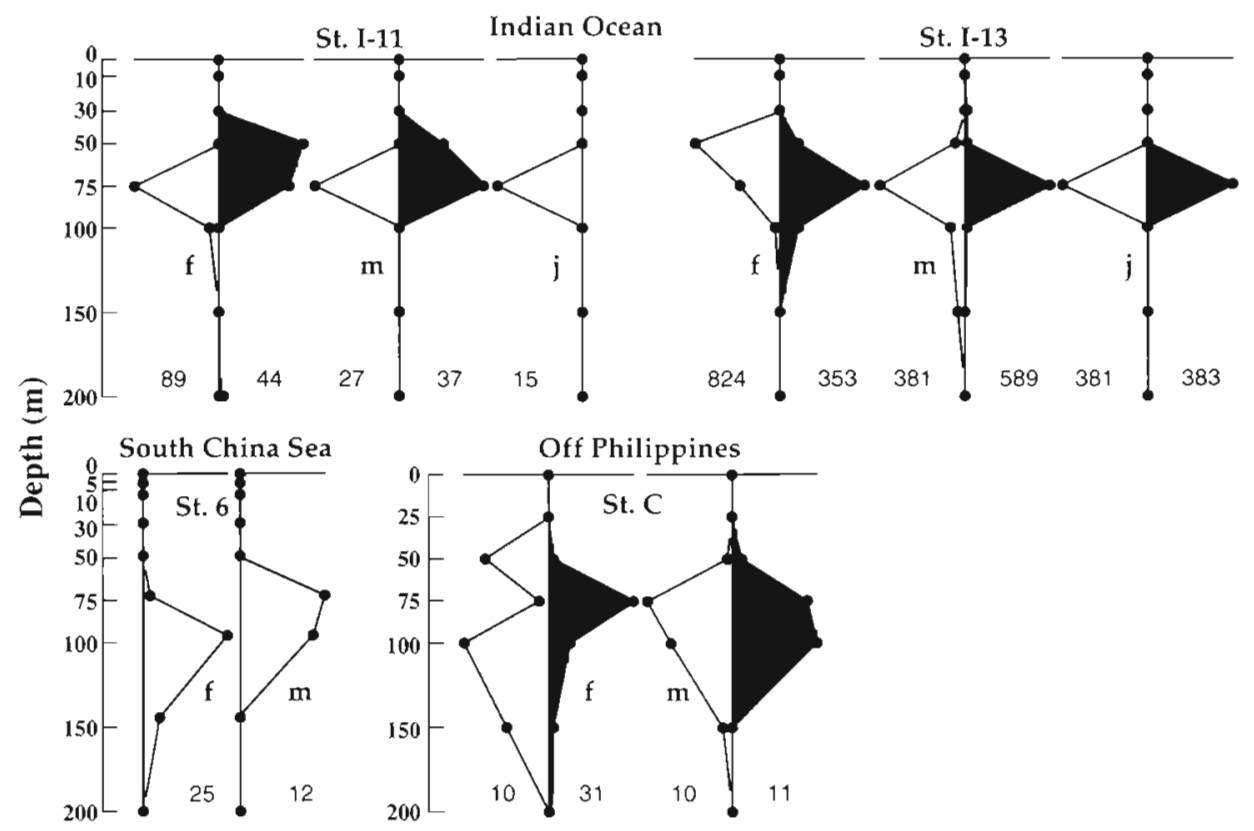


In the South China Sea, only females were collected in the daytime with a peak between 75 and $100 \mathrm{~m}$.

In the eastern waters off the Philippines, both sexes of Sapphirina intestinata were distributed between 50 and $150 \mathrm{~m}$ during the day and at night.

Sapphirina angusta Dana (Fig. 9). In the eastern Indian Ocean, both sexes and juveniles were concentrated between 30 and $50 \mathrm{~m}$ in daytime. At night, females had a peak at $30 \mathrm{~m}$ at Stn I-11 and at $75 \mathrm{~m}$ at Stn I-13. Males were not collected at night.

Sapphirina ovatolanceolata Dana (Fig. 9). At Stn I13 in the eastern Indian Ocean, both sexes and the juveniles were concentrated at $30 \mathrm{~m}$ in the daytime. At night, both sexes showed bimodal distribution with peaks at 10 and $75 \mathrm{~m}$. At Stn 1 in the subtropical Pacific, females occurred widely between 30 and $100 \mathrm{~m}$ with a peak at $80 \mathrm{~m}$ in the daytime, while males occurred between 30 and $75 \mathrm{~m}$ with a peak at $60 \mathrm{~m}$.

Sapphirina sinuicauda Brady (Fig. 9). In the eastern Indian Ocean, $S$. sinuicauda were mostly distributed in the upper $30 \mathrm{~m}$ in the daytime and dispersed as deep as $100 \mathrm{~m}$ at night. At Stn I-13, a bimodal distribution was observed at night in both sexes.

Copilia mirabilis Dana (Fig. 10). In general, the depth range of $C$. mirabilis was broader than that of Sapphirina. In the eastern Indian Ocean, the greater portion of females and males had peaks at $30 \mathrm{~m}$, while another small peak occurred at $100 \mathrm{~m}$ in the daytime at Stn I-11. Juveniles also showed 2 peaks; one at $10 \mathrm{~m}$ and the other at $150 \mathrm{~m}$. At night, females showed a bimodal distribution with marked peaks at 30 and $100 \mathrm{~m}$, while males and juveniles were concentrated at $30 \mathrm{~m}$. At Stn 1-13, females and males were concentrated at $75 \mathrm{~m}$ in the daytime and dispersed between 10 and $75 \mathrm{~m}$ at night, the females occurring as deep as $200 \mathrm{~m}$. Juveniles were distributed in the upper $10 \mathrm{~m}$ in the daytime and dispersed between 10 and $75 \mathrm{~m}$ at night.

In the subtropical and tropical waters of the western Pacific, they showed broad distributional patterns ranging between 0 and $200 \mathrm{~m}$ at most stations. Adults showed a tendency to be distributed deeper over a greater range than did juveniles (e.g. Stns 1, 4, 7, 9 and 11). There was no marked difference between day and night stations. The day-night series at Stn 4 showed a slight shoaling of the females at night.

In the eastern waters off the Philippines, both sexes and juveniles occurred at 50 to $75 \mathrm{~m}$ in the daytime. At night, males dispersed with peaks at 25 and $150 \mathrm{~m}$, while females showed the same pattern as in the daytime.

Copilia quadrata Dana (Fig. 11). C. quadrata also showed wide vertical ranges. At Stn I-11 in the eastern Indian Ocean, both sexes occurred between 30 and $150 \mathrm{~m}$ with a peak at $150 \mathrm{~m}$ in the daytime. At night, the females were concentrated between 50 and $75 \mathrm{~m}$, while the males were still concentrated at $150 \mathrm{~m}$. At the daytime stations in the western Pacific, they showed a wide vertical range from 0 to $200 \mathrm{~m}$
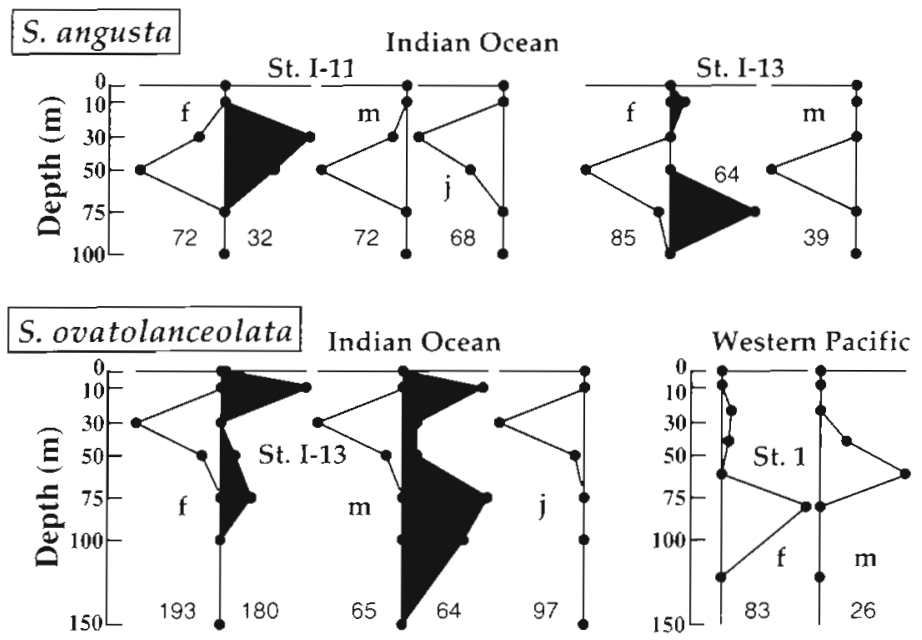

Fig. 9. Sapphirina angusta, S. ovatolanceolata, and $S$ sinuicauda. Vertical distributions of females ( $f$ \}, males $(m)$ and copepodid juvemiles (j) in the Indian Ocean and the western Pacific. Symbols as in Fig. 3

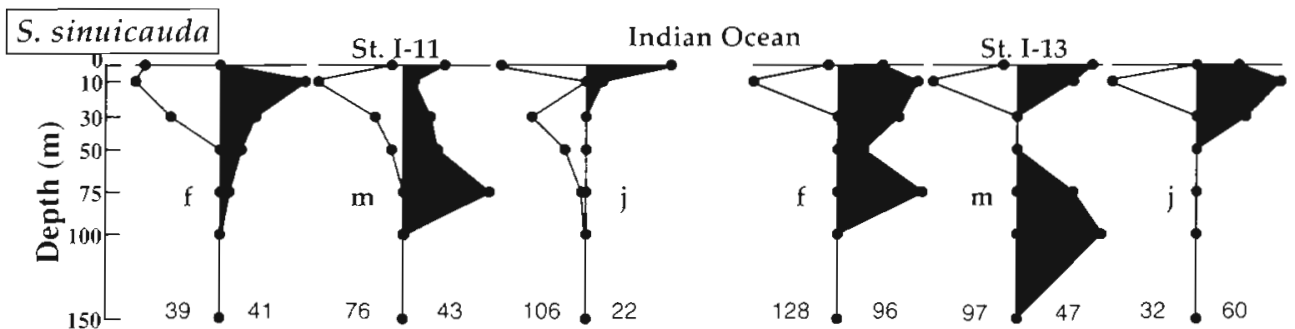




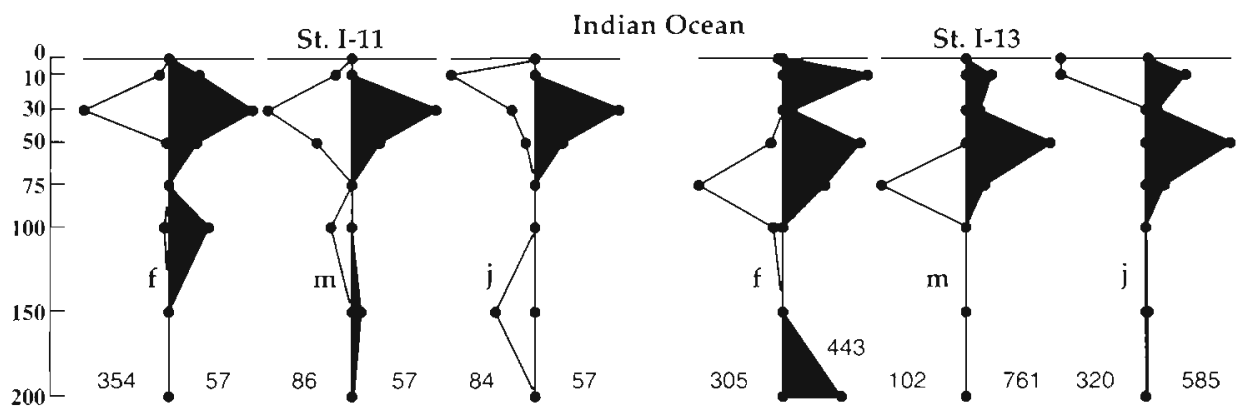

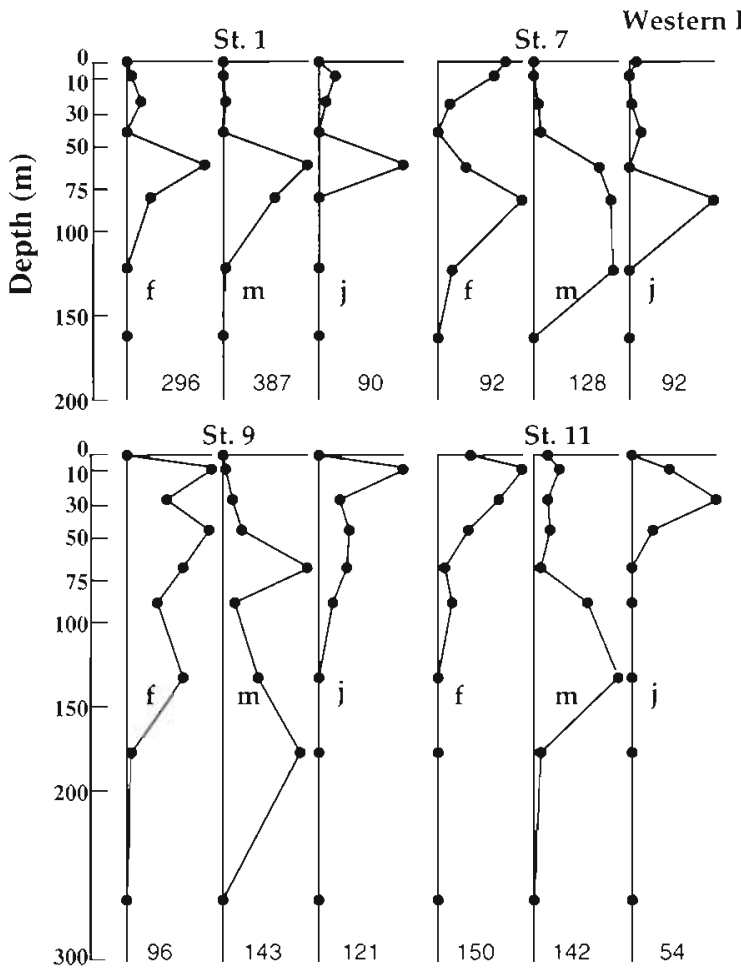

In the eastern waters off the Philippines, they were concentrated between 50 and $75 \mathrm{~m}$ in the daytime. At night, the females dispersed, while males did not show marked distributional change.

\section{DISCUSSION}

\section{Specific patterns of vertical distribution}

In the present study, the sapphirinid copepods as a whole were collected essentially in the upper $200 \mathrm{~m}$ layers, and are considered a typical group of epipelagic copepods.

Fig. 12 summarizes the specific patterns of vertical distribution, represented by the averages and ranges of the weighted mean depths for the female and male of each species. Three groups can be recognized: (1)
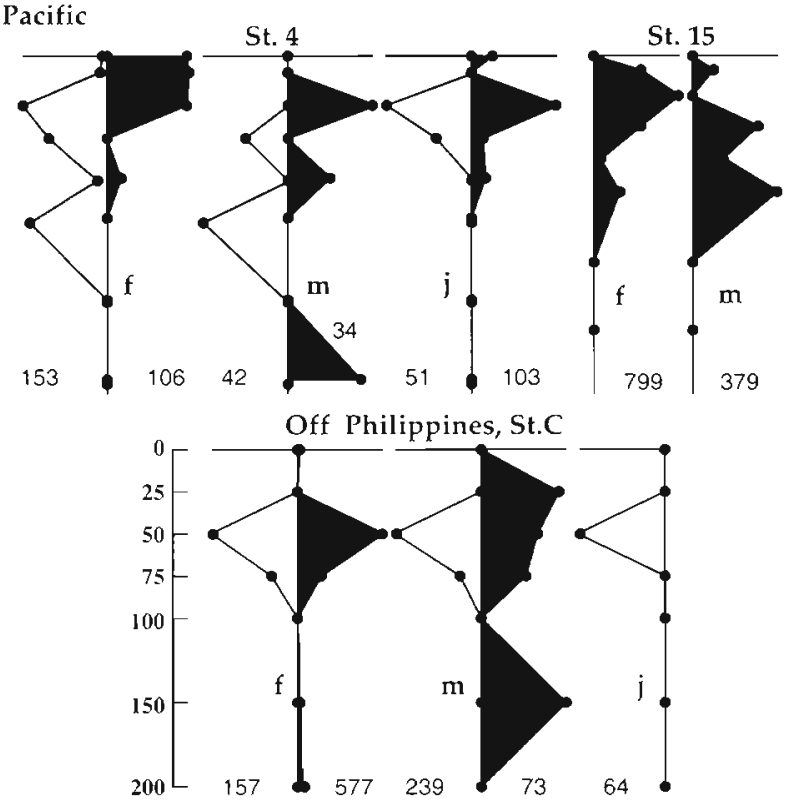

Fig. 10. Copilia mirabilis. Vertical distributions of females (f), males ( $m$ ) and copepodid juveniles (j) in the Indian Ocean, the western Pacific and off the Philippines. Symbols as in Fig. 3

the upper epipelagic species which have their daytime mean depths mainly in the mixed layer $(0$ to $50 \mathrm{~m})$ (Sapphinina auronitens, S. gastrica, S. nigromaculata and S. stellata; see also Fig. 13); (2) the lower epipelagic species which have their mean depths mainly below the mixed layer ( 50 to $100 \mathrm{~m}$ ) both day and night (S. intestinata and S. metallina; see also Fig. 13); and (3) the species which have their mean depths mainly between 50 and $100 \mathrm{~m}$, but with broader vertical ranges than the above group, often occurring both in the mixed layer and below $100 \mathrm{~m}$ (Copilia mirabilis and C. quadrata; see also Fig. 13).

Comparable data with enough precision are available for a few species in the Cape Verde Islands region in the northeastern Atlantic (Boxshall 1977) and the Red Sea (Böttger-Schnack 1990a, b). In the Cape Verde Islands region, Copilia mirabilis females were most abundant in the upper $60 \mathrm{~m}$ both during the day 

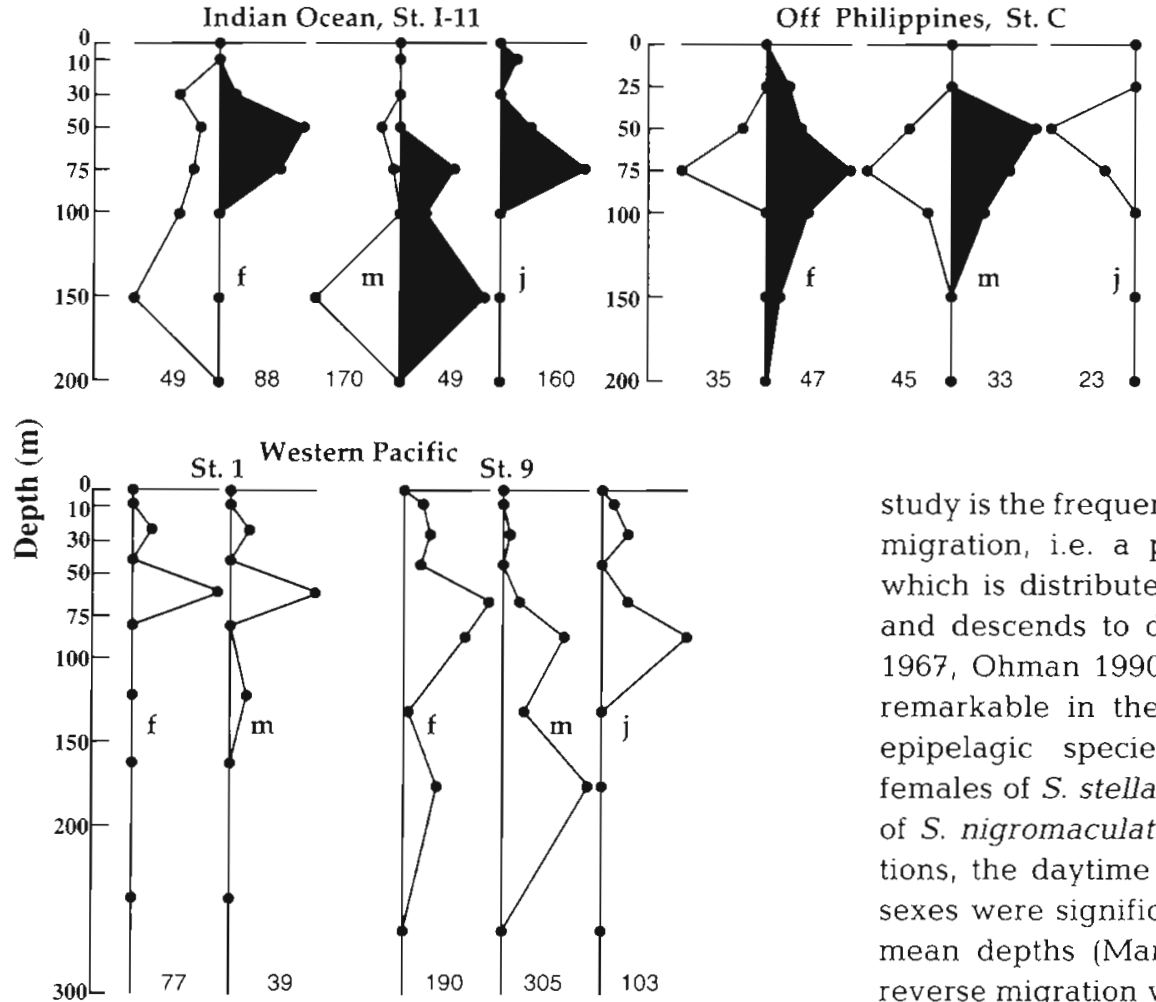

and at night, while males were abundant at 20 to $100 \mathrm{~m}$ in the daytime and 0 to $60 \mathrm{~m}$ at night, which suggested an upward migration by the males at night. Both sexes of Sapphirina metallina were concentrated at about 50 to $100 \mathrm{~m}$ both during the day and at night. $S$. auronitens were present in the upper $100 \mathrm{~m}$ both in the daytime and at night (Boxshall 1977). In the Red Sea, S. metallina were distributed in the upper $200 \mathrm{~m}$ with maximal abundance in the 40 to $100 \mathrm{~m}$ layer both during the day and at night. $C$. mirabilis was mostly restricted to the upper $60 \mathrm{~m}$ (BöttgerSchnack 1990a, b).

The present results are consistent with these records in that the sapphirinids have been collected mostly from the epipelagic zones, that Sapphirina metallina have been collected from the lower part of the epipelagic zone, and that Copilia mirabilis occasionally showed normal migration. Relatively shallow distributions were observed in C. mirabilis in the above studies, but these fall within the variations observed in the present study, as discussed below.

\section{Reverse migration and regional variation}

The most striking characteristic in the vertical pattern of the sapphirinids revealed in the present study is the frequent occurrence of reverse diel vertical migration, i.e. a pattern exhibited by a population which is distributed in shallow layers in the daytime and descends to deeper layers at night (Hutchinson 1967, Ohman 1990). The reverse migration was most remarkable in the males and females of the upper epipelagic species Sapphirina gastrica, and the females of $S$. stellata and $S$. auronitens, and the males of $S$. nigromaculata; for the combined data of all stations, the daytime mean depths in these species and sexes were significantly shallower than the nighttime mean depths (Mann-Whitney $U$-test, $p<0.05$ ). The reverse migration was also observed at 1 station in the lower epipelagic species $S$. metallina.

In the species exhibiting marked reverse migration, the mean population depths of the male and the females coincided well in the daytime, while at night they were occasionally different (Sapphirina gastrica, S. metallina: Stn I-11; S. nigromaculata: Stns I-11, I-13 and $C_{;}$S. stellata: Stn I-13). This, coupled with com-

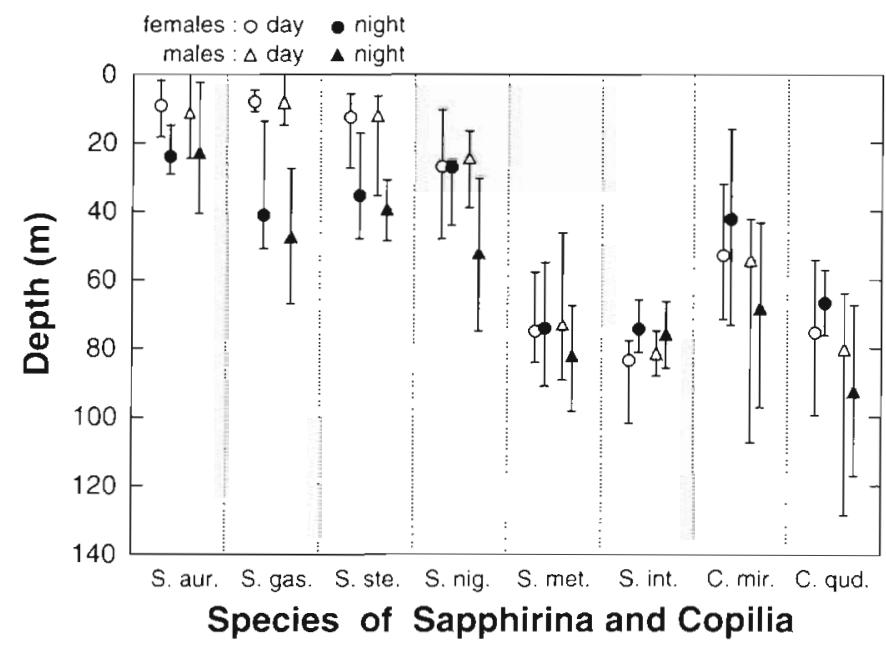

Fig. 12. The averages $(0, \boldsymbol{0}, \Delta, \mathbf{\Delta})$ and ranges (vertical lines) of mean depths in species of the family Sapphirinidae. Data from all vertical series are included. S. aur.: Sapphirina auronitens; S. gas.: S. gastrica; S. ste.: S. stellata; S. nig.: S nigromaculata S. met.: S.

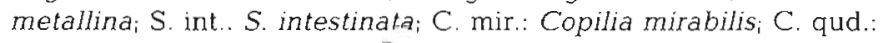
C. quadrata 
monly observed near-surface patches of the sapphirinids (T. Ishimaru \& K. Kawaguchi pers, comm.; authors' unpublished observation), leads to a hypothesis that the daytime ascent is related to mating (see 'Discussion: Iridescence, light condition and vertical pattern').

There was considerable variation between stations in the occurrence of reverse migration. For example, in Sapphirina auronitens, the females, males and copepodid juveniles equally showed marked reverse migration at Stn I-13, but only the juveniles did at Stn I-11 (Fig. 3); no marked difference was observed in temperature, salinity and chl a profiles between these stations except that the surface salinity was much lower at Stn I-13 than at Stn I-11 (Fig. 2). Similar differences were observed in the females of $S$. gastrica and $S$. nigromaculata between Stns I-11 and I-13 (Figs. $4 \& 6$ ). It was also indicated that nighttime distributions were occasionally bimodal, particularly in the females, while daytime distributions were mostly unimodal, as in $S$. auronitens (Fig. 3; Stns I-13, 11 and 15), S. gastrica (Fig. 4; Stns I-11, I-13 and 6), S. metallina (Fig. 7; Stns I-13, 6 and 11), suggesting that only a part of the population migrates at night in some conditions.

An extreme example of regional difference of vertical pattern was observed in the male and the female of Sapphirina auronitens and the male of $S$. stellata during the time-series sampling in the South China Sea (Figs. $3 \& 5$; Stn 6), where only the shallow, daytime population was captured in significant numbers. An examination of deeper samples down to $1000 \mathrm{~m}$ at this station showed that only negligible numbers of $S$. auronitens and the males of $S$. stellata were collected at night throughout the water column.

At present there is no plausible explanation for the causal mechanisms and ecological significance of these occasional variations. However, in the nighttime distribution such biological factors as predation avoidance, patchiness, feeding activities, parasitism, and association with faster-swimming animals (see Hardy 1936, Furuhashi 1966, Heron 1973) may be possible causes for the observed variations, which require further, more direct observations on feeding and behavior.

\section{Vertical pattern and environmental parameters}

Fig. 13 shows the relationships of the depths of maximum abundance of each species' population with the depths of the mixed layer and the depths of the chlorophyll maximum. In Fig. 13A, the diagonal line represents the points where the depth of maximum abundance of a species coincides with the depth of the mixed layer, i.e. the area above the diagonal repre- sents populations in the mixed layer, while the area below represents those below the mixed layer. While the depth of maximum abundance in each species and the depth of the mixed layer did not show any significant correlation, several species showed distinct clusters and day-night changes, similar to the pattern described for the mean depths.

The depth of maximum abundance and the depth of chlorophyll maximum did not show any marked correlation; most species were distributed in layers much shallower than the deep chlorophyll maximum (Fig. 13B). Only Sapphirina metallina and S. intestinata appear to be distributed relatively close to the deep chlorophyll maximum both during the day and at night.

\section{Iridescence, light condition and vertical pattern}

As partially mentioned in the 'Introduction', the welldeveloped eyes, particularly in the females, and the impressive iridescence of the male, coupled with the daytime vertical segregation in the sapphirinids, lead to a hypothesis that the daytime vertical pattern may be regulated primarily by the light conditions in the water column. However, in the present study no direct measurement was made of the depth distributions of ambient light wavelength and intensity. Therefore, the following discussion is based on an assumption that throughout the studied area the light conditions in the water column were that of typical tropical/subtropical oceanic water which may be accepted for most stations (see 'Hydrographic conditions').

Circumstantial observations necessary to test this hypothesis may be (1) the vertical change of light condition in the upper $200 \mathrm{~m}$, (2) the depth distributions of the species in the daytime, and (3) the iridescent color pattern of the species, while more direct evidence for possible mechanisms and proximate cues may be provided by observations on the light sensitivity and lightinduced behavior of individual copepods. At present, available information is limited to the 3 points mentioned above.

The light intensity and spectrum in the ocean are determined by scattering and spectral absorption of water, which are related to the abundance of phytoplankton, non-chlorophyllous particles and dissolved organic matter (Jerlov 1976, Prieur \& Sathyendranath 1981, Baker \& Smith 1982). At depth in tropical/subtropical open ocean the ambient light is restricted to the blue part of the spectrum, because blue light can penetrate to a depths of more than about $75 \mathrm{~m}$, whereas the spectrum in the upper layer involves longer wavelengths as well, successively absorbed with increasing depth in the order red, yellow to green 

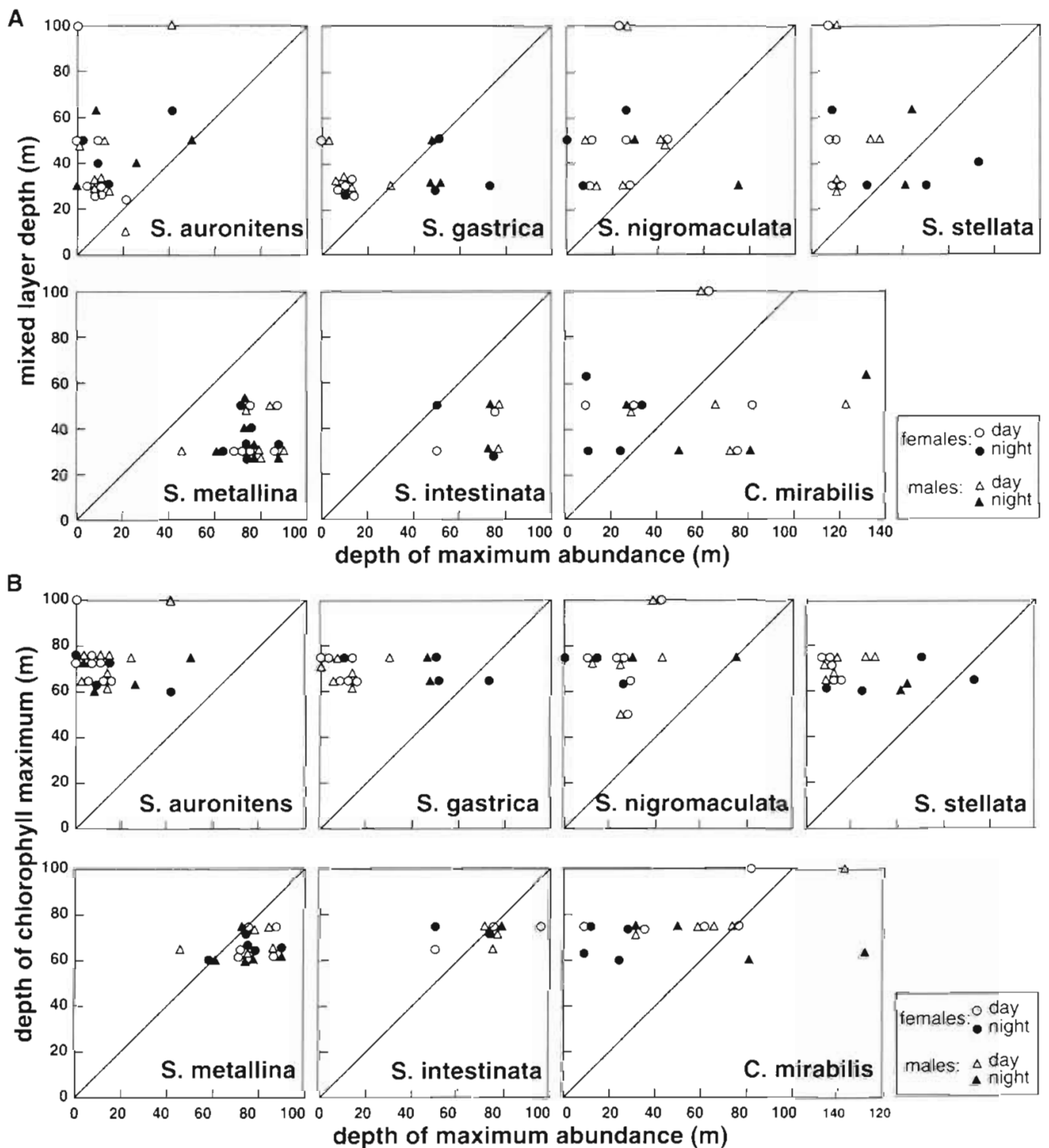

Fig. 13. Relationships of the depths of maximum abundance of each species' population with (A) the depths of the mixed layer and (B) the depths of chlorophyll maximum. Data from all stations, where surface mixed layer and chlorophyll maximum are detectable, are included. S.: Sapphirina; C.: Copilia. Diagonal line represents the points where the depth of maximum abundance of a species coincides with the depth of the mixed layer

(Levine \& MacNichol 1982). The iridescent colors of the male of Sapphirina auronitens, S. gastrica, S. nigromaculata and $S$. stellata, which are distributed in the upper epipelagic zone, are all yellowish, or metallic gold. Of the lower epipelagic species, S. metallina shows strong iridescence with broad spectrum while $S$. angusta and $S$ intestinata show blue iridescence. Copilia mirabilis and C. quadrata, which are distributed mainly in deeper layers and have broad ranges, show blue iridescence (Chae \& Nishida 1994, unpubl. data).

Thus there appears to be a good correspondence between the specific iridescent colors and the depth distributions of species, and, hence, their ambient light spectrum and intensity: the yellowish iridescence of the upper epipelagic species corresponds to the light with longer wavelengths which is available only in the upper layer, while the blue iridescence of the deeper species corresponds to the blue light which is the only light available in that layer. The lower epipelagic species Sapphirina metallina iridesces quite differently from other species; the exact nature of its iridescence is still poorly understood.

The iridescence of the sapphirinids is caused by the reflecting platelets in the epidermal cells of the copepod's dorsal integument, through the interference and 
reflection of light incident to the dorsal surface of the copepod (Chae \& Nishida 1994). Extremely high reflectivities (close to the aluminum plate used as a control) of this reflecting system have been measured by microscopic spectrophotometry (authors' unpubl. data) On the other hand, both sexes of Sapphirina and the female of Copilia have 3 separated cups of the nauplius eye: a small medial cup and 2 lateral cups hugely elongated into what appear to be a pair of binoculars. Each lateral eye has an enormous biconvex lens and a pear-shaped lens. Males of Copilia have only the median eye in which the 3 cups are together with 2 smaller lenses (Elofsson 1966, 1969, Moray 1972, Land 1984). The lateral eyes are of the 'scanning' type which have been suggested to have an image-forming function (Gregory et al. 1964, Elofsson 1969, Wolken \& Florida 1969, Downing 1972, Land 1981, 1984). If we assume that the well-developed eyes of the sapphirinids, particularly in the females, are used for searching for conspecific mates, then the male iridescence can be considered as a mechanism, at least in part, of increasing male visibility. Since the upward ambient light is minimal in clear oceanic water (Denton 1970), the yellowish iridescence of the shallow species, when viewed from above, will produce a high contrast of the copepod against the dark-blue background in terms of both the light intensity and spectrum. When viewed from below, the complementary effect of the platelets (Chae \& Nishida 1994) will produce weak, blue color of the copepod against the strong, whitish background. Similarly, the blue iridescence of the deep species will produce a contrast as high as possible at the depth against the background with almost negligible light intensity, and vice versa from underneath. The extremely well-developed eyes with large lenses only of the females in the deep-living Copilia species (Gregory et al. 1964) would provide an additional, morphological support to this presumed mate-finding mechanism in a light-limited condition. However, it should also be noted here that the lens-eyes may also play an important role in feeding, as suggested by the atrophied mouth appendages only in the Copilia males (G. A. Boxshall pers. comm, see also Land 1984).

In summary, the circumstantial observations as discussed above are consistent with the hypothesis that the daytime vertical pattern of the sapphirinids is dependent primarily on the light condition in the ocean as a proximate cue. If we assume the mate-finding mechanism as presented above, the ecological role of the reverse migration and the iridescent color, and the coupling of these phenomena in the sapphirinids seem to be unique in oceanic animals. Reverse migration is known in various planktonic animals, such as cnidarians (Hamner et al. 1982), amphipods (Shulenberger 1978) and copepods (Hure \& Scotto di Carlo 1974, Hairston 1980, Ohman 1983, 1990). Different ultimate causes, or ecological roles, of reverse migration have been proposed for different cases. These include: avoidance from predation by invertebrate predators (Hairston 1980, Ohman 1983, 1990); maintenance of populations within their respective habitats (Bosch \& Taylor 1973, Hure \& Scotto di Carlo 1974); and maintenance of the symbiotic system between a scyphomedusa and zooxanthellae (Hamner et al. 1982). Predation avoidance is one of the possible causes for the nighttime distribution in the sapphirinids, but we have little information on their predators, which awaits a further study. To our knowledge, however, no cases other than the sapphirinids have been reported where daytime shoaling is assumed to work as a major element of a mating system. On the other hand, reflecting epidermal structures are also known in many oceanic animals. A well-known example is the silvery skin layers of pelagic fishes for camouflaging (see Denton 1970 for review). In the sapphirinids, however, the iridescent platelet system is considered to give highest visibility to the copepod, a role exactly opposite both to camouflaging and predation avoidance. Probably, the sapphirinids respond through other sets of mechanisms to predation; the almost transparent body of the females (Boxshall 1981) and a spiral mode of swimming frequently exhibited by the males (authors' unpubl. data) may be included.

The mate-finding mechanism proposed here, however, still involves many unsolved problems, which may be summarized by the following questions. Do the sapphirinids sense the image produced by the contrasts of light intensity, or do they also have a sense of color? How do the females recognize conspecific mates in the presence of the males of different species with iridescence of a similar color? What is the ultimate cause for the deeper, nighttime distribution: is it for predation avoidance, feeding, spawning, resting, or something else? Are sapphirinids parasitic, carnivorous, or herbivorous, and when and how do they eat? How are their distributions related to the distributions of other pelagic animals? For a better understanding of the biology and evolution of this unique and interesting group of copepods, studies on the in situ behavior, light sensitivity and light-induced behavior, and feeding ecology coupled with diel activity rhythms are necessary.

Acknowledgements. We thank. Drs G. A. Boxshall and M. D. Ohman for their valuable comments on the manuscript. We also thank the officers and crew members of the RV 'Hakuho Maru' for their help in sampling at sea. 


\section{LITERATURE CITED}

Baker, K. S., Smith, R. C. (1982). Bio-optical classification and model of natural waters 2. Limnol. Oceanogr. 27: 500-509

Bosch, H. F., Taylor, W. R. (1973). Diurnal vertical migration of an estuarine cladoceran, Podon polyphemoides, in the Chesapeake Bay. Mar. Biol. 19: 172-181

Böttger-Schnack, R. (1990a). Community structure and vertical distribution of cyclopoid copepods in the Red Sea. I. Central Red Sea, autumn 1980. Mar. Biol. 106: 473-485

Böttger-Schnack, R. (1990b). Community structure and vertical distribution of cyclopoid copepods in the Red Sea. II. Aspects of seasonal and regional differences. Mar. Biol. 106: $487-501$

Boxshall, G. A. (1977). The depth distribution and community organization of the planktonic cyclopoids (Crustacea: Copepoda) in the Cape Verde Islands regions. J. mar. biol. Ass. U.K. 57: 543-568

Boxshall, G. A. (1981). Community structure and resource partitioning - the plankton. In: Forey, P. L. (ed.) The evolving biosphere. British Museum (Natural History), London, p. 143-156

Chae, J., Nishida, S. (1994). Integumental ultrastructure and color patterns in the iridescent copepods of the family Sapphirinidae (Copepoda: Poecilostomatoida). Mar. Biol. 119: $205-210$

Dana, J. D. (1852). Crustaced, U.S. Exploring Expedition, Vol. 13. C. Sherman, Philadelphia

Denton, E. J. (1970). On the organization of reflecting surfaces in some marine animals. Phil. Trans. R. Soc. Lond (Ser. B) 258: 285-313

Downing, A. C. (1972). Optical scanning in the lateral eyes of the copepod Copilia. Perception 1: 247-261

Elofsson, R. (1966). The nauplius eye and frontal organs of the non-Malacostraca (Crustacea). Sarsia 25: 1-128

Elofsson, R. (1969). The ultrastucture of the nauplius eye of Sapphirina (Crustacea: Copepoda). Z. Zellforsch. 100: $376-401$

Furuhashi, K. (1966). Droplets from the plankton net. XXIII. Record of Sapphirina salpae Giesbrecht from the North Pacific, with notes on its copepodite stages. Publs Seto mar. biol. Lab. 14: 123-127

Gregory, R. L., Ross, H. E., Moray, N. (1964). The curious eye of Copilia. Nature 201: 1166-1168

Hairston, N. G. Jr (1980). The vertical distribution of diaptomid copepods in relation to body pigmentation. Am. Soc Limnol. Oceanogr. Spec. Symp. 3: 98-110

Hamner, W. M., Gilmer, R. W., Hamner, P. P. (1982). The physical, chemical, and biological characteristics of a stratified, saline, sulfide lake in Palau. Limnol. Oceanogr. 27 (5) 896-909

Hardy, A. (1936). Observation on the uneven distribution of oceanic plankton. 'Discovery' Rep. 11: 511-536

Heron, A. C. (1973). A specialized predator-prey relationship between the copepod Sapphirina angusta and the pelagic tunicate Thalia democratica. J. mar. biol. Ass. U.K. 53 $429-435$

Hirota, Y. (1987). Vertical distribution of euphausiids in the western Pacific Ocean and the eastern Indian Ocean. Bull Jap. Sea reg. Fish. Res. Lab. 37: 175-224

Ho, J S. (1991). Phylogeny of Poecilostomatoida: a major order of symbiotic copepods. Bull. Plankton Soc. Jap. (Spec. vol.): $25-48$

Hure, J., Scotto di Carlo, B. (1974). New patterns of diurnal vertical migration of some deep-water copepods in the Tyrrhenian and Adriatic Seas. Mar. Biol. 28: 179-184

Hutchinson, G. E. (1967). A treatise on limnology. II Introduc- tion to lake biology and the limnoplankton. John Wiley \& Sons, New York

Huys, R., Boxshall, G. A. (1991). Copepod evolution. The Ray Society, London

Jerlov, N. G. (1976). Marine optics. Elsevier, Amsterdam

Land, M. F. (1981). Optics and vision in invertebrates. In: Autrum, H. (ed.) Handbook of sensory physiology, Vol. VIl/6B. Springer-Verlag, Berlin, p. 401-438

Land, M. F. (1984). Crustacea. In: Ali، M. A. (ed.) Photoreception and vision in invertebrates. Plenum Press, New York, p. $408-417$

Lehnhofer, K. (1926). Copepoda: Copilia Dana 1849, Systematik und Verbreitung der Gattung. Deutsche TiefseeExpedition 1898-1899 23(3): 1-64

Lehnhofer, K. (1929). Copepoda: Sapphirina J. V. Thompson 1829, Systematik und Verbreitung der Gattung. Deutsche Tiefsee-Expedition 1898-1899 22(5): 1-80

Levine, J. S., MacNichol, E. F. (1982). Color vision in fishes. Scient. Am. 246(2): 108-117

Moray, N. (1972). Visual mechanisms in the copepod Copilia. Perception 1. 193-207

Motoda, S. (1971). Devices of simple plankton apparatus V. Bull. Fac. Fish. Hokkaido Univ. 22: 10.1-106

Nishida, S., Marumo, R. (1982). Vertical distribution of cyclopoid copepods of the family Oithonidae in the western Pacific and Eastern Indian Oceans. Bull. Plankton Soc. Jap. 29: $99-118$

Ohman, M. D. (1983). Reverse diel vertical migration: an escape from invertebrate predators. Science 220 1404-1407

Ohman, M. D. (1990). The demographic benefits of diel vertical migration by zooplankton. Ecol. Monogr. 60(3): 257-281

Otake, T., Tsukamoto, K. (1994). Preliminary report of the Hakuho Maru Cruise KH-91-4. Ocean Research Institute, Univ. of Tokyo, Tokyo

Pearre, S. (1973). Vertical migration and feeding in Sagitta elegans Verrill. Ecology 54(2): 300-314

Prieur, L., Sathyendranath, S. (1981). An optical classification of coastal and oceanic waters based on the specific spectral absorption curves of phytoplankton pigments, dissolved organic matter, and other particulate materials. Limnol. Oceanogr. 26(4):671-689

Rajaram, L. K., Krishnaswamy, S. (1981). Distribution of Sapphirina (Copepoda, Cyclopoida) in the south-east Indian Ocean along $110^{\circ} \mathrm{E}$. Bull. Dept. mar. Sci. Univ. Cochin 12 $1-22$

Roe, H. S. J., Angel, M. V., Badcock, J., Domanski, P., James, P. T., Pugh, P. R., Thurston, M. H. (1984). The diel migrations and distributions with a mesopelagic community in the North East Atlantic. 1. Introduction and sampling procedures. Prog. Oceanogr. 13: 245-268

Schmidt, W. J. (1949). Altes und Neues über Strukturfarben im Tierreich. Giessener naturw. Vortr. 6: 30-37

Sewell, R. B. S. (1947). The free-swimming planktonic copepoda, systematic account. Scient. Rep. John Murray Exped 8 (1): $1-303$

Shulenberger, E. (1978). Vertical distributions, diurnal migrations, and sampling problems of hyperiid amphipods in the North Pacific central gyre. Deep Sea Res. 25: 605-623

Simidu, U. (1990). Preliminary report of the Hakuho Maru Cruise KH-88-1. Ocean Research Institute, Univ. of Tokyo, Tokyo

Wolken, J. J., Florida, R. G. (1969). The eye structure and optical system of the crustacean copepod, Copilia. J. Cell Biol. 40: $279-285$

Wyrtki, K. (1964). The thermal structure of the eastern Pacific Ocean. Dt. hydrogr. Z., ErgänzHft. Rh. A(6): 1-84

Manuscript first received: July 19, 1994

Revised version accepted: November 29, 1994 